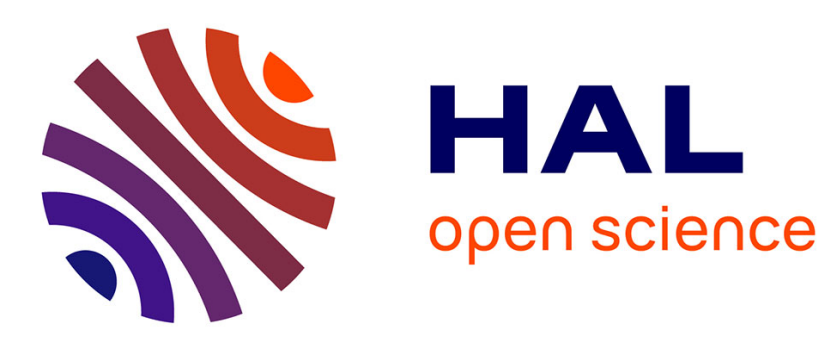

\title{
University teachers' perceptions of Online Informal Learning of English (OILE)
}

Denyze Toffoli, Geoff Sockett

\section{To cite this version:}

Denyze Toffoli, Geoff Sockett. University teachers' perceptions of Online Informal Learning of English (OILE). Computer Assisted Language Learning, 2015, 28 (1), pp.7-21. 10.1080/09588221.2013.776970 . hal-01227584

\section{HAL Id: hal-01227584 \\ https://hal.science/hal-01227584}

Submitted on 18 Nov 2015

HAL is a multi-disciplinary open access archive for the deposit and dissemination of scientific research documents, whether they are published or not. The documents may come from teaching and research institutions in France or abroad, or from public or private research centers.
L'archive ouverte pluridisciplinaire HAL, est destinée au dépôt et à la diffusion de documents scientifiques de niveau recherche, publiés ou non, émanant des établissements d'enseignement et de recherche français ou étrangers, des laboratoires publics ou privés. 


\title{
University teachers' use of their students' Online Informal Learning of English (OILE)
}

\author{
Denyze Toffoli \& Geoff Sockett, Université de Strasbourg
}

ince 2008 we have been developing a multi-faceted study into Online Informal Learning of English (OILE). In practice, OILE involves language development through online activities such as social networking, streaming and/or downloading television series or films, listening to music on demand and web browsing.

UNESCO's definition of Open Educational Resources (OER) in its Guidelines for Open Educational Resources in Higher Education (2011) is that "OER are materials used to support education that may be freely accessed, reused, modified, and shared" (p.1). OILE is not therefore strictly speaking usage of OER and we are aware of the proviso in the Guidelines specifying that "'OER' is not synonymous with online learning, eLearning or mobile learning" (p.v), be it informal. OILE differs from OER in that the learning produced is largely incidental rather than targeted, as the aim of the activities is not language acquisition. Rather the language users see themselves as involved in leisure activities of which language learning is merely a by-product. It is the student and not the teacher or course designer who identifies the resources to be used and these resources were not developed specifically for language learning.

One of the specificities of language learning (as opposed to say mechanics, biology or literature) is that the learning objectives are not content (especially in a purely communicative or competence-based perspective), but rather the vehicle that carries the content: a capacity to use the language in question. To this extent language learning can build upon very diversified contents, as the "content-based language learning" approaches over the last thirty years (Mohan, 1986; Crandall, 1987; Snow, 2005) have demonstrated. OILE thus extends to any and potentially all internet content in English. To qualify as an OILE resource, the content need only be consulted and used by language learners.

We have chosen to anchor our research within the theoretical framework of complex dynamic systems theory (Larsen-Freeman \& Cameron, 2008), as this seems the most apt to account for the organic, multifarious, constantly changing and interacting nature of such learning. Our aim is to understand the mechanisms at work in the (parts of the) systems outside instructed learning, even where this latter involves computer mediation, distance, or other recent developments in instruction. In terms of language learning, research into this area could help us to understand the part OILE plays in an overall learning process and thus provide input into future instructional design, for example.

Our investigations began with a survey of 228 non-English-major students' practices with informal learning of English (Toffoli \& Sockett, 2010). Their most prevalent activities are viewing American series (with or without subtitles in English) and listening to on-demand music with accompanying lyrics. Other important results of this survey include:

- Students listen more to English online than they read it.

- They listen as much to TV series and films in English as to music and very few listen to music alone. 
- In terms of written language, students read in interactive contexts (forums, instant messaging, social networks, e-mail) as much as they do in a purely receptive mode (consulting sites).

- Through social media, students are involved in writing online, albeit mostly in a responsive, repetitive and short-statement mode.

- Very few students speak in English online, regardless of support and content.

A second study (Sockett $\&$ Toffoli, 2012) aimed to gain a more detailed view of these practices. Six learners recorded their daily activities in English over an 8-week period. Our findings varied from the sublime to the ridiculous (one of our participants actually logged an average of over 50 hours of on-line activity in English per week - the median for the five others was closer to 5). Results show primarily that these students are

- users of English (as opposed to "just" learners of the language),

- $\quad$ engaging in activities for their pleasure and entertainment (TV series and music on-demand),

- but also using the English language for various pragmatic purposes, such as:

0 to gain new skills (for example consulting on-line tutorials for computer programmes),

0 to further their investigations into other areas of study (computer graphics or Japanese)

o to achieve personal goals (plan a holiday, translate online content).

While we did not find extensive material allowing us to have insight into uptake of new language, we did find some indications of how students process the language input they are exposed to. These include

- extensive listening,

- listening for gist,

- listening for pronunciation,

- listening and doing online research to clarify meaning,

- developing fluency and vocabulary through written interaction (e-mail, Facebook, participation in forums and chatrooms),

- building vocabulary both incidentally (intensive exposure to certain expressions in a TV series, for example) and intentionally (looking up, translating or otherwise managing content in an effort to understand and master the words used).

In an attempt to discover more about the specific language these learners are most exposed to in one of their preferred activities, Sockett (2011a) performed cluster frequency analyses of 4-word chains in a 500 000 -word corpus of television scripts (1 season each of 5 popular series). His results indicate that the material listened to is high in "ordinary" language content (conversations concerning daily life), corresponding to B1 descriptors for speaking in the CEFRL. These include structures that are problematic for French learners (the example "I want you to" being illustrated by the literal translation from French "I want that you"). Sockett hypothesises that regular exposure to these items (as would be the case for a student who is "faithful" to a favourite series) might lead to adoption of the standard English form (ibid, p.13). He is currently (2012) working on a study attempting to measure uptake of such items. 


\section{Objectives and scope of the teacher beliefs survey}

In view of the seeming potential of OILE activities for language uptake, this paper focuses on a new survey examining OILE from the other side of the educational relationship: teachers' perceptions of and beliefs about these practices, both as "practices" and as influences on the language learnt by the students.

This survey explores 30 French university English professors' knowledge and use of student practices with OILE. This is slightly fewer than the 50 responses we had hoped to obtain, but sufficiently representative to allow some generalizations.

Our attempts to identify any correlations with gender, age or national origin of the teachers reveal no significant results, with one possible exception. We have however gained some insight into their awareness of the OILE phenomenon amongst students, the perceived or imagined effects of these practices on their students' English and the ways they do or do not integrate this knowledge into their own teaching.

In our initial study, fully $97 \%$ of the students surveyed answered questions attesting to regular on-line activity in English. If we average the teachers' estimations of the number of students concerned, we find they believe it concerns less than half (44\%). Graph 1 below indicates the distribution of teachers and their beliefs about numbers of students practicing OILE. The three teachers working in the language centre where the initial study was carried out also provide estimations below 50\%.

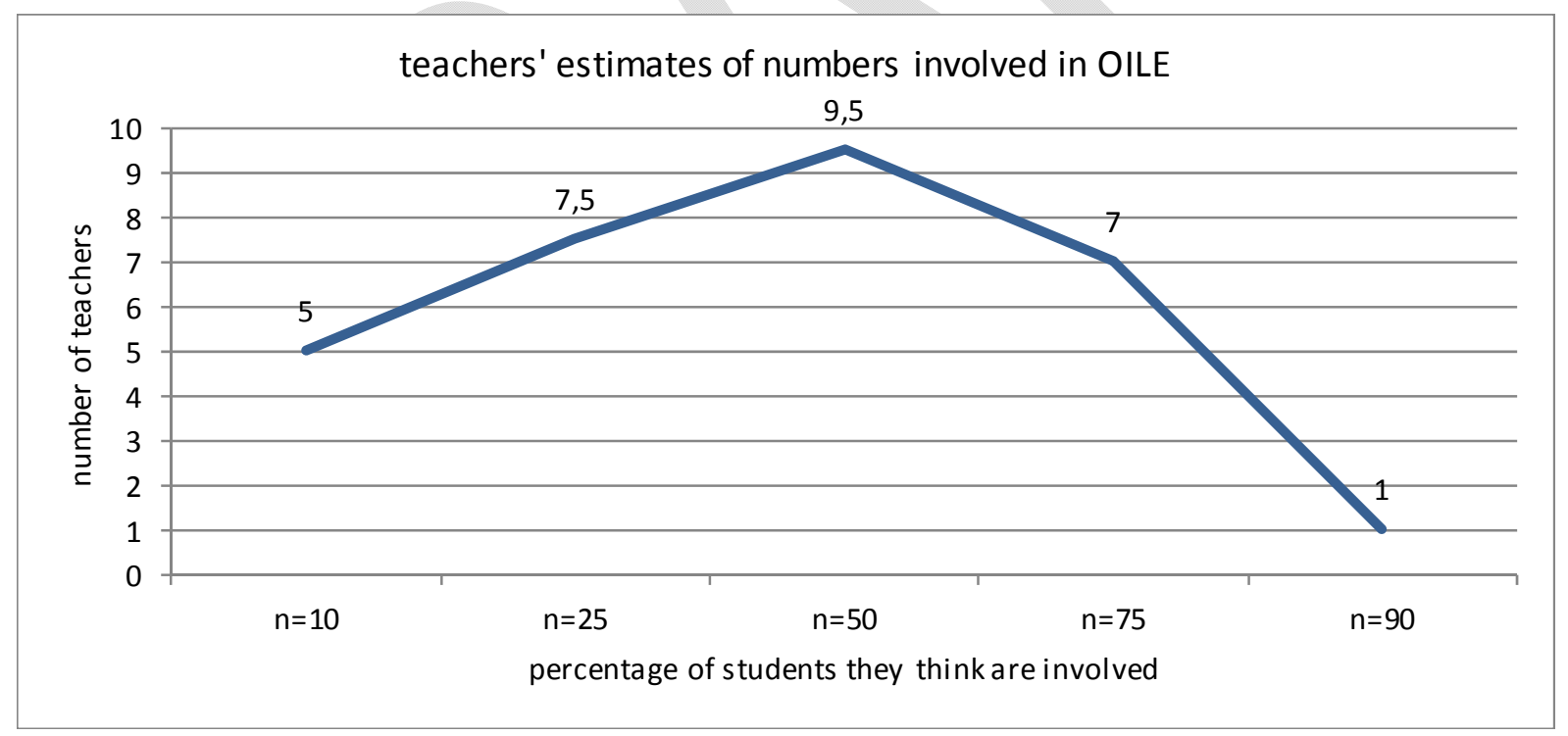

\section{Graph 1}

Correlations were sought between belief that OILE activities are prevalent among non-specialist students and three independent variables: age, gender and nationality of respondents. A statistically significant correlation at the 0.05 level ( 0.41 using the Phi correlation) was found for nationality. Indeed $50 \%$ of respondents indicating their nationality as French considered that OILE was a minority activity, whereas none of the English or American teachers surveyed believed this to be the case. 
While the university teachers we questioned are certainly familiar with students' on-line activity in English, their responses are nuanced (see Graph 2 below) and only 21 of the 30 affirm with conviction that they are aware of such activity ${ }^{1}$. Given the numbers of students who actually declare to be engaged in such activities, a surprising number (10 out of 30$)$ teachers feel that this only concerns a minority of students.

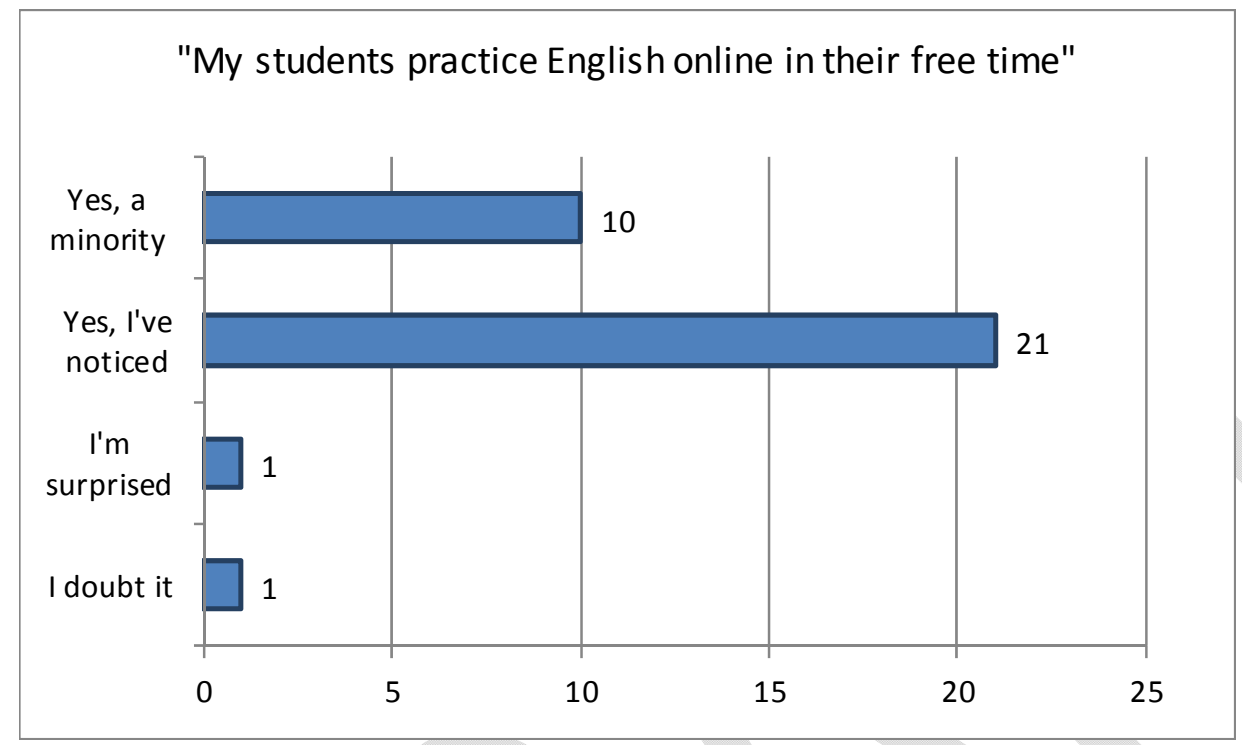

Graph 2

Most teachers (23) feel that this number is increasing and none find it to be diminishing (Graph 3).

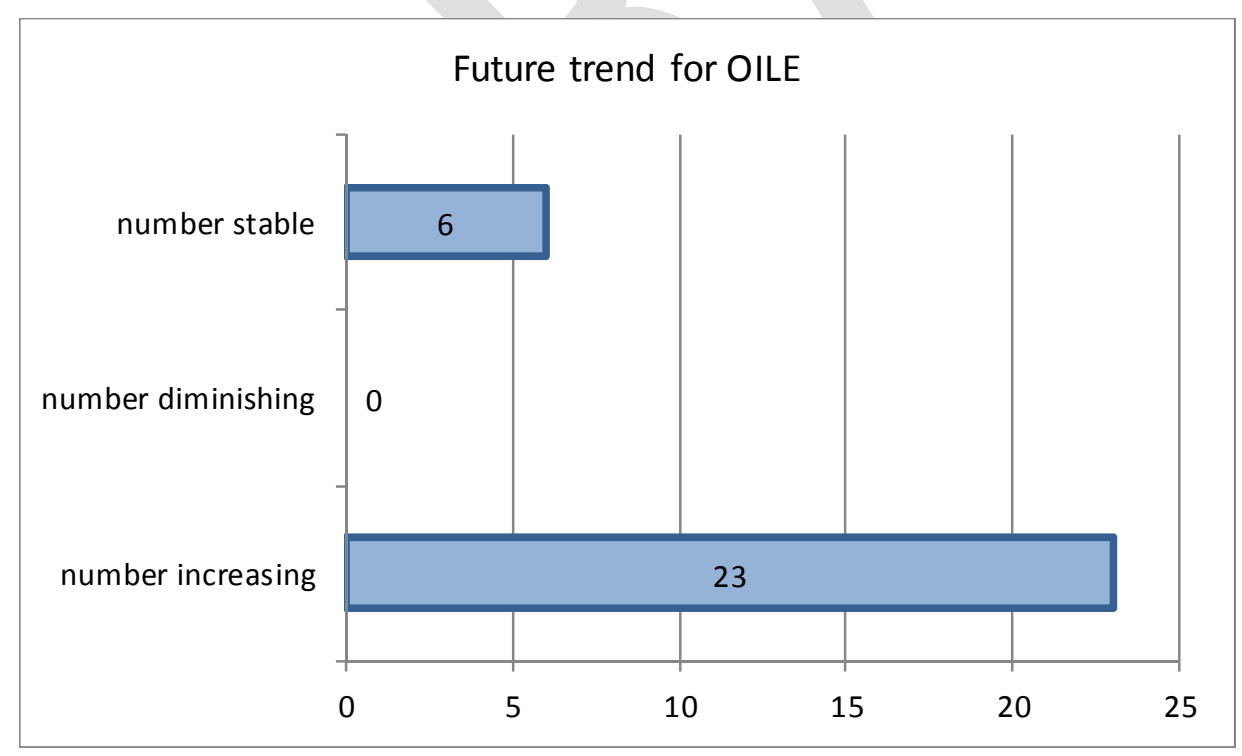

\section{Graph 3}

${ }^{1}$ The total number is over $100 \%$, as 3 teachers chose 2 answers each. 


\section{What are the effects of OILE ?}

Teachers do believe OILE affects in-class behavior as well as English skills (Graph 4). Twenty-five of them (5/6) feel that this effect is positive, although four mitigate this by doubling it with a negative response. These represent the same four of the five who find it negative. Four others qualify the effects as neutral.

Thus, only one teacher in our sampling actually qualifies the overall effects of OILE as negative. She justifies this position noting, "they think that watching TV series is studying at a university level".

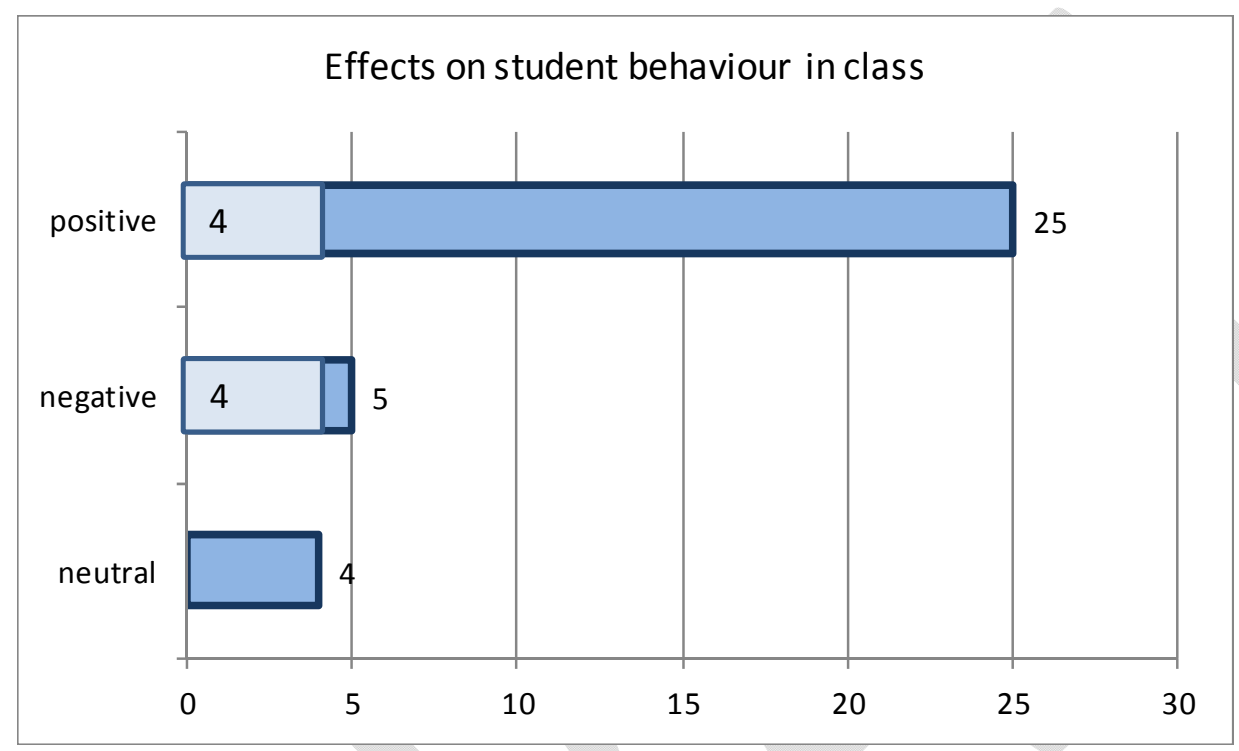

\section{Graph 4}

On the positive side, teachers cite increased curiosity about English, increased motivation to learn the language, often promoted by the students' impression of being able to understand, more confidence and a general feeling of being at ease with the spoken language. They find that for some, English has become a part of their daily lives. They notice more familiarity with English / American cultural habits and that students appear to have greater knowledge about English-speaking countries than in the past. Some students ask their teachers to explain or translate expressions they have heard in their favorite series, or exclaim in class "yes, that's like in [Lost, or whatever]".

Other remarks on the negative side indicate a "copy and paste" approach to learning and a lack of critical distance. One teacher is concerned that the level of language input "is not appropriate to the university context".

Practically all of the teachers in the study believe that these practices have a positive influence on students' skills in English, as Graph 5 below indicates. 


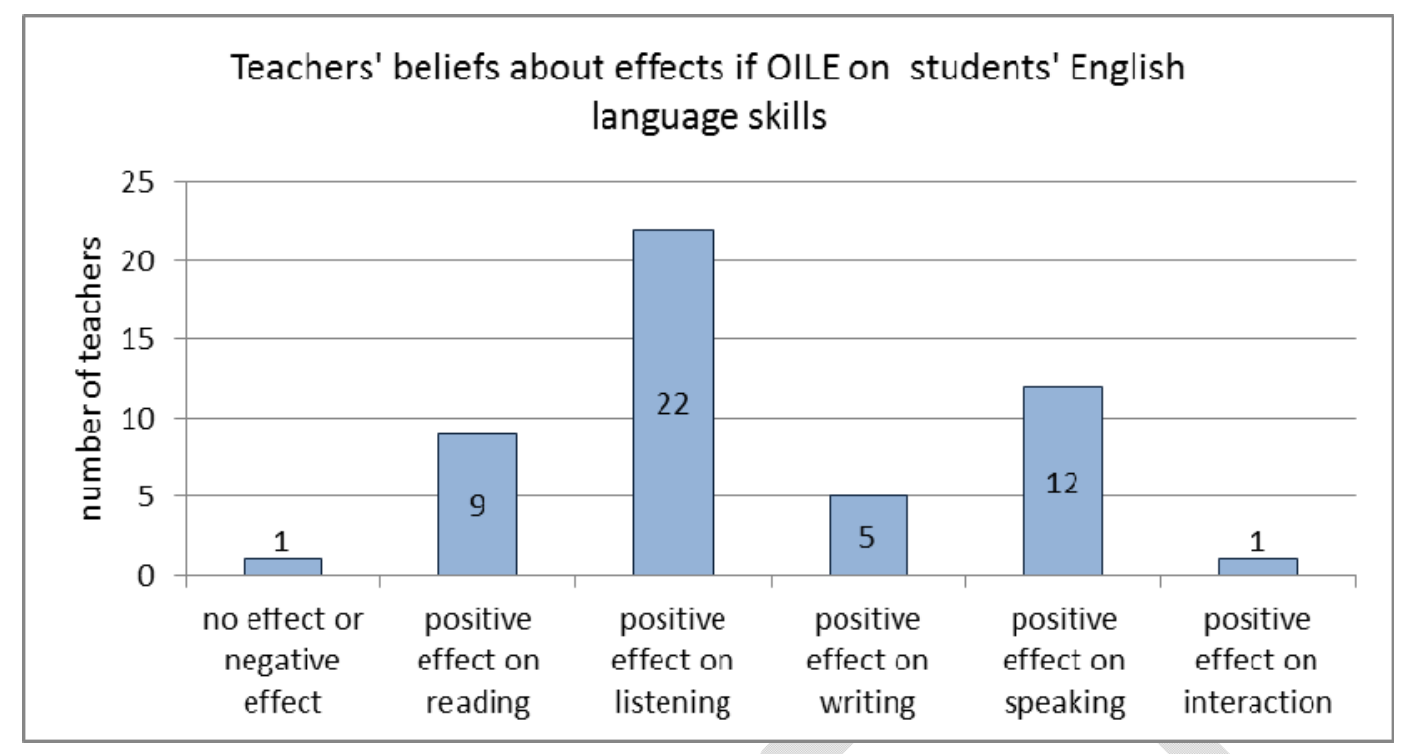

Graph 5

The results concerning listening, where 22 of the 30 teachers find a positive effect, would tend to corroborate the results of our first study, where students indicated spending time primarily on listening activities. The noticeable effects on speaking are more surprising (12 teachers find such an effect) and can perhaps be related to the extensive exposure to native-speaker accents and discourse, as our 2009 survey indicated that students do not themselves participate to any great extent in speaking activities online. In the same way, our insights into student practices indicate that the types of writing they are involved in online are mostly in a responsive, repetitive and short-statement mode, quite different from the types of writing required from them by English teachers. This might explain why only five teachers feel there to be an effect on writing.

Specific examples provided by teachers to back-up their claims of influence on language skills include the facts that students

- are less disturbed by rapid speech,

- use current idiomatic expressions with appropriate pronunciation,

- have better comprehension,

- demonstrate better pronunciation in general,

- are more fluent.

One (non-native) teacher stated that there was no evidence of improved pronunciation in class.

\section{Influences of OILE on teaching practices}

Slightly over half of the teachers say that students' practices with online resources influences their teaching. As examples, two refer to their own use of internet in preparing courses or seeking responses to student questions in class, four indicate using television series in class; one refers to students' favourite series in her teaching and another works with them on how to exploit these resources specifically for learning English. She encourages them in this type of practice, shows them how they can use these types 
of activities to improve their English, has them keep learning logs and tries to get them to realize that in fact they use English every day and fluency is "just around the corner" (Teacher \#5).

Slightly over a third of the teachers (12) indicate that they would like to adjust their teaching practices to better integrate this new given in the English learning landscape, although only a few provide specific reasons. Among those stated are: to build motivation, "to be in phase with my students' practices and interest them as much as possible", "it is that type of English that students will need most during their lifetime - that which they will come into most contact with".

Among those who answer that they don't intend to modify their teaching, reasons cited include the fact that their subject area doesn't lend itself to such contents, that the teaching programmes are very rigid and cannot be adapted, that they don't want to be the only one in their department to make such changes (although they don't indicate exactly what kinds of change they envisage).

\section{Perceived problems}

Finally, teachers were questioned about perceived problems with using these online practices in the classroom. Their answers (Graph 6) predictably target the illegal aspects of downloading songs or series and also hesitations related to intrusion into the private lives of their students.

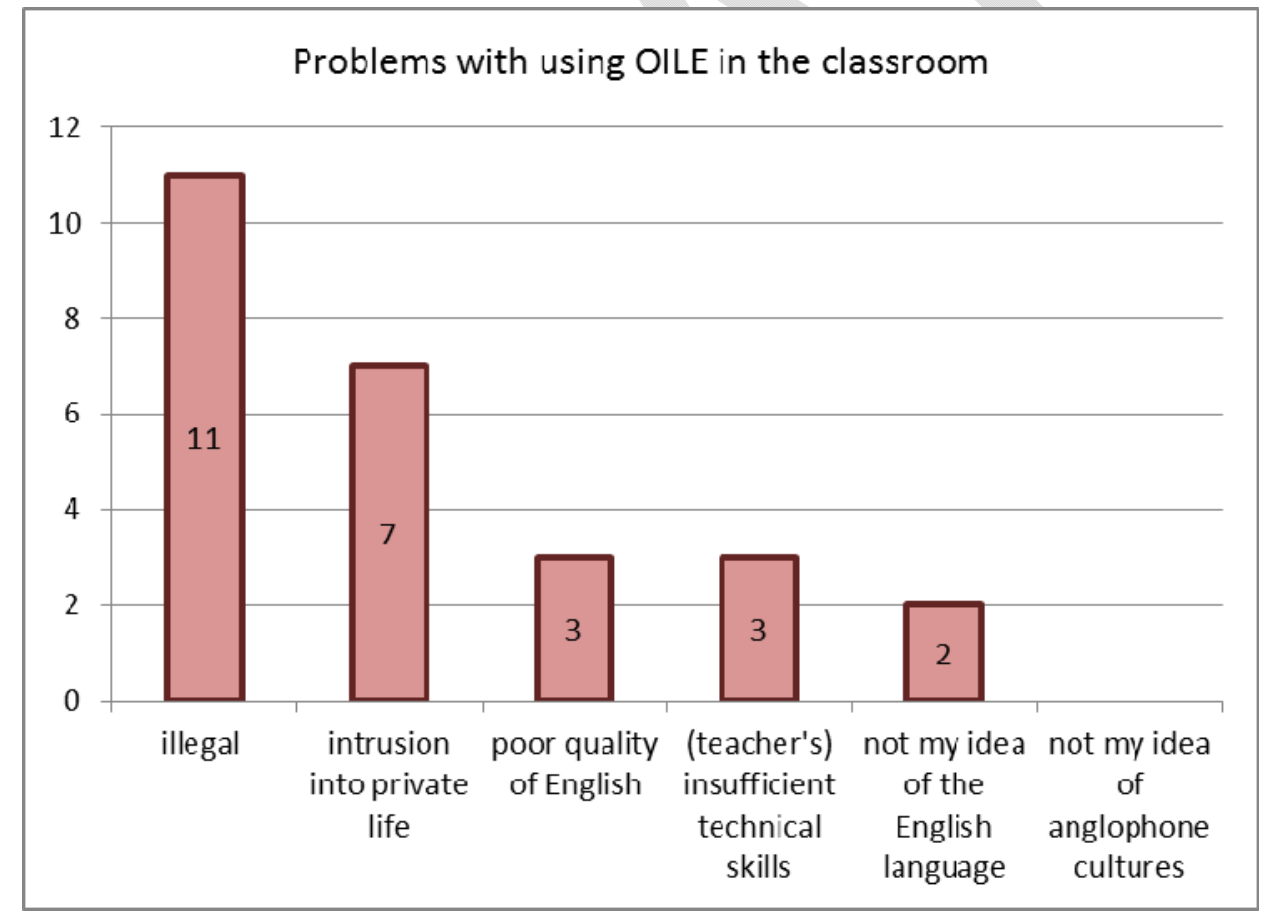

Graph 6

One teacher comments quite extensively on this question: "My idea of teaching to specialists of other disciplines means that I do not subscribe at all to the problems you quote in question 9. Yes, some activities are illegal. And they do them anyhow. We may as well build something on that. Bad quality 
English? I don't know what that means: if we're speaking of register, we can also use that to construct something on style. It's still English and that's what's important" (Teacher \#5).

\section{One teacher's position}

In order to flesh out this composite description of teachers' attitudes towards OILE, a look at one teacher's position (Teacher \#5) could be read as somewhat typical of the group. These are the opinions of a 34 year-old French woman teaching in a political sciences institute, which she considers to be a "privileged context". She thinks that OILE concerns about $50 \%$ of her students, that the number is increasing and that this has both positive and negative effects on English courses. She notices improvement in both the listening and speaking skills of her students, due, in her opinion, mostly to watching series, and cites the use of "netspeak" idioms as proof of participation in OILE. She thinks that internet has brought English into the daily life of her students, occasionally refers to their extra-curricular contacts with English and at the same time considers such contacts to be part of her students' private life and therefore that it does not really have a place in the classroom. Despite this, she gets her students to keep learning logs and tries to encourage them to make use of these resources in a more "educational" and less passive way.

This teacher demonstrates a rather paradoxical position, that may be typical of many in the profession. Although young, she is already somewhat disconnected from the practices of her students. She feels she has no place in the "private life" of her students, yet she senses the learning potential of what they do in their free time and would like to capitalize on it. This position is backed up by similar practices of others; teacher \#8, for example "asked my students to list the daily activities that bring them into contact with English. They shared their ideas in order to develop new practices (podcasts, radios, series, Facebook or Twitter pages configured in English, funny sites like Fmylife, etc)". We again encounter the idea that somehow teachers would like to "tap into" these activities in English, but do not as yet do so in any systematic or targetted way.

Teacher \#5 also seems to feel there is a "right" and a "wrong" way to learn English, or at least an "effective" way (where cognitive processes such as questioning the content and "noticing" play an important role) and an "ineffective" way (identified as learner passivity): "these activities are not yet really, I believe, used for learning (not enough "conscious processing"). In the end they are really quite passive (ok, they watch a series, films in English, read forums, but haven't yet developed the reflexes of a "specialist" - questioning the vocabulary used, picking out structures or simply remarking language used."

Both the potential and the wariness expressed here are shared by Teachers \#9 and \#7. The first states: "The phenomenon is interesting especially for students who cannot travel, but annoying for the false conclusions that they can come to or the register of English which is not always perceived by them as too familiar." The second finds: "The principle drawback with these practices is in my opinion that they don't hone a rigourous mind. Students often surf on the internet without really paying attention and absorb things without any ulterior systematisation, with the risk of reinforcing vague, indeterminate knowledge, a phenomenon all too present with students in non-language disciplines."

These converging comments about language learning methodology lead us to wonder why teachers express these types of hesitation. Is it to maintain or reinforce their role as an educator (authority), is it 
because they have no confidence in the previous education of their students to have prepared them for autonomous learning, is it because they feel only one model of learning is correct or appropriate, ... ?

One of the conclusions we may come to, based on the comments of 5 or 6 teachers from our sample, is that teachers seem to be convinced of the potential interest of internet resources for language learning, especially concerning the spoken language, but feel the need for adaptations or educational frameworks for such resources. This would thus take such content out of the realm of the fully authentic and of course out of the area of informal learning and bring it more fully into the scope of OER. 


\section{Bibliography}

Butcher, N. (2011). A Basic Guide to Open Educational Resources. Vancouver: Commonwealth of Learning. http://oer.unescochair-ou.nl/?wpfb dl=29

Crandall, J. A. (Ed.). (1987). ESL through content-area instruction: Mathematics, science, and social studies. Englewood Cliffs, NJ, and Washington, DC: Prentice Hall and Center for Applied Linguistics.

Unesco / Commonwealth of Learning (2011). Guidelines for Open Educational Resources (OER) in Higher Education. Vancouver: Commonwealth of Learning. http://unesdoc.unesco.org/images/0021/002136/213605e.pdf

Larsen-Freeman, D., \& Cameron, L. (2008). Complex Systems and Applied Linguistics. Cambridge, UK: Oxford University Press.

Mohan, B. (1986). Language and content. Reading, MA: Addison-Wesley.

Sockett,G. (2011a). "From the cultural hegemony of English to online informal learning: Cluster frequency as an indicator of relevance in authentic documents." ASp 60 : 5-20.

Sockett,G. (2011b). "Les processus cognitifs de résolution de problèmes pour l'apprentissage des langues dans des environnements multimédia : Apprentissage informel et réseaux sociaux." Les Cahiers de l'Acedle, 8(1) : 29-46. http://acedle.org/spip.php?article3184

Sockett, G. \& Toffoli, D. (2012). "Beyond learner autonomy: A dynamic systems view of the informal learning of English in virtual online communities." ReCALL 24(2): 138-151.

Snow, M. A. (2005). A model of academic literacy for integrated language and content instruction. In E. Hinkel (Ed.), Handbook of research in second language learning (pp. 693-712). Mahwah, NJ: Erlbaum.

Toffoli, D. \& Sockett, G. (2010). "How non-specialist students of English practice informal learning using web 2.0 tools." ASp, 58: 125-154. 